\title{
An Induced Enzyme in X-irradiated Escherichia coli: Comparison with Lethal Effects
}

\author{
By J. L. MOORE \\ Experimental Radiopathology Research Unit, Medical Research Council, \\ Hammersmith Hospital, Ducane Road, London, W. 12
}

(Received 13 April 1965)

\begin{abstract}
SUMMARY
The effect of $\mathrm{X}$-rays on the synthesis of induced $\beta$-D-galactosidase was examined with Escherichia coli strain B and three of its mutants, i.e. the sensitive strain $\mathrm{BS}$ and two resistant strains $\mathrm{B} / \mathrm{r}$ and $\mathrm{B} / \mathrm{H}$. With the parent strain $\boldsymbol{E}$. coli в the extent of radiation-induced lethal damage depended on conditions of culture after irradiation, whereas radiation-induced inhibition of $\beta$-D-galactosidase was unaffected by the composition of the culture medium. The sensitivity of radiation damage to induction of $\beta$-D-galactosidase was about the same for $E$. coli strains B, B/r and B/H, the dose required to give $37 \%$ survival being $42 \pm 6 \mathrm{krad}$; in $E$. coli Bs the sensitivity to radiation was three times as great. Enzyme induction was one-half to one-third as radiosensitive as viability for the strains $\mathrm{B} / \mathrm{r}$, B/H and Bs but with strain B it was one-tenth as sensitive when Oxoid Nutrient Medium was used. Oxygen enhancement ratios for lethal effects were always smaller than those for inhibition of enzyme synthesis.
\end{abstract}

\section{INTRODUCTION}

Many biochemical effects of ionizing radiation are difficult to observe unless very large doses are used, as compared with those used to study loss of reproductive ability. It has been found, however, that the ability of bacteria to synthesize induced enzymes may be inhibited by doses of X-rays comparable with those used to establish survival curves (Billen \& Lichstein, 1952; Pauly, 1959, 1963; Dewey, 1962; Pollard \& Vogler, 1961). There is evidence that ionizing radiations interfere with many synthetic pathways in bacteria; the synthesis of proteins as well as nucleic acids has been shown to be affected (Gros, 1960; Pauly, 1963). Swenson \& Setlow (1964) found that ultraviolet inactivation of $\beta$-D-galactosidase M-RNA was more sensitive than general protein synthesis. Kameyama \& Novelli (1962) found that if the bacteria were ultraviolet-irradiated before induction $\beta$-D-galactosidase synthesis was more sensitive than general protein synthesis. If it be accepted that the synthesis of each protein depends on a specific expression of the genetic code, then the study of $\mathrm{X}$-ray effects on the synthesis of a particular enzyme may be expected to throw light on the pathways leading to that synthesis. Pauly (1959) investigated the inhibition by $\mathrm{X}$-rays of the synthesis of lysine decarboxylase in 'Bacterium cadaveris'. The exclusion of oxygen from the irradiated material decreased the effects of the X-rays by a factor of four. Dewey (1962) reported that the ability of a strain of Pseudomonas to synthesize histidine-oxidizing enzymes 
was partly protected against radiation by glycerol. Pollard \& Vogler (1961) observed that the doses required to inhibit induction of $\beta$-D-galactosidase in Escherichia coli were similar to those reported by Pauly for inhibition of lysine decarboxylase induction in ' $B$. cadaveris'. The lethal effects of ionizing radiation on bacteria may be modified by a variety of treatments, and in particular $E$. coli strain B and some of its mutants are very susceptible to the influence of cultural conditions after irradiation (Alper \& Gillies, 1958 $a, 1960 b$; Gillies \& Alper, 1959). The inhibition of enzyme synthesis presented an end-point other than lethality for testing the modifying effects of some of these conditions, and also for comparing the response of $E$. coli B with that of mutants which differed greatly from it in sensitivity to radiation in respect of survival.

\section{METHODS}

\section{Organisms}

The strains of bacteria used were Escherichia coli $\mathrm{B}, \mathrm{B} / \mathrm{r}$, Bs and $\mathrm{B} / \mathrm{H}$. E. coli $\mathrm{B} / \mathrm{H}$ is a resistant mutant of $\boldsymbol{E}$. coli В isolated in this laboratory. Cultures were grown in Oxoid Nutrient Broth and aerated by gentle shaking in an incubator at $37^{\circ}$ for $3 \frac{1}{2} \mathrm{hr}$ and then harvested while in logarithmic growth. Suspensions were prepared for irradiation by centrifuging down and washing the organisms three times in $0.066 \mathrm{M}$-phosphate buffer $\left(\mathrm{pH}=7 \cdot 0\right.$ ). Suspensions containing $10^{9}$ bacteria $/ \mathrm{ml}$. were used for measuring inhibition of enzyme induction and about $5 \times 10^{5}$ bacteria/ $\mathrm{ml}$. for measuring survival.

\section{Enzymes}

For induction of $\beta$-D-galactosidase $5 \mathrm{ml}$. of double-strength nutrient medium were placed in a conical flask with $3 \mathrm{ml}$. sterile distilled water; $1 \mathrm{ml}$. of irradiated bacterial suspension was added, the flask placed in a water bath and gently shaken at $37^{\circ}$. Two minutes later $1 \mathrm{ml}$. of $1 \%(\mathrm{w} / \mathrm{v})$ lactose solution was added to the flask and a sample immediately removed. Further samples were taken at intervals of $15 \mathrm{~min}$. over the next $75 \mathrm{~min}$. The samples were placed in test tubes containing chloramphenicol to give a final concentration in excess of $100 \mu \mathrm{g} . / \mathrm{ml}$., to arrest induction of enzyme. Two drops of toluene and two drops of $1 \%(w / v)$ sodium deoxycholate were added to the samples which were shaken vigorously for $1 \mathrm{~min}$. and then placed in an incubator at $37^{\circ}$ for a further $15 \mathrm{~min}$. This last procedure ruptured the cell wall and membrane so that the enzyme was released into the surrounding medium.

The amount of $\beta$-D-galactosidase was estimated by a modification of the method of Lederberg (1950); with $o$-nitrophenyl $\beta$-D-galactoside (ONPG) as substrate the $o$-nitrophenol (ONP) is split off, being measured in a spectrophotometer (Unicam) at $420 \mathrm{~m} \mu$. Samples of enzyme were placed in Unicam glass cuvettes with buffer $(\mathrm{pH}=7 \cdot 0)$ and the substrate ONPG at a final concentration of $0.0028 \mathrm{M}$. The cuvettes were placed in a cell carrier fitted with a thermostatic device to keep the contents at $28^{\circ}$. (The cuvette carrier was designed by $\mathrm{A}$. Lowe and modified by W. Siddiqi and J. Woo Sam in this Unit so that four $1 \mathrm{~cm}$. cuvettes can be kept at controlled temperatures). Measurements of ONP were taken every few minutes until the increase in concentration was linear with time.

Enzyme activity was measured in millimoles-o-nitrophenol liberated $/ \mathrm{min} . / \mathrm{ml}$. of initial culture. 
Survival curves were determined by suitably diluting samples removed from the irradiation vessel, plating on Nutrient Agar, the plates being incubated overnight at $37^{\circ}$. The nutrient media used were Oxoid Nutrient Agar (CM 55), Oxoid Nutrient Broth (CM 67), Difco Nutrient Agar and Difco Nutrient Broth (Difco Laboratory Detroit, U.S.A.). These were prepared from commercial preparations of dehydrated granules. In some experiments these media were supplemented with $1 \%(\mathrm{w} / \mathrm{v})$ lactose.

\section{Irradiation and dosimetry}

Radiation was from an X-ray unit operating without added filtration at either $250 \mathrm{kV}$., $12 \mathrm{~mA}$. or $250 \mathrm{kV}$., $15 \mathrm{~mA}$. Dose rates were $1000 \mathrm{rad}$. or $2000 \mathrm{rad} . / \mathrm{min}$. as determined by ferrous dosimetry. The irradiation vessel used was designed by Alper (1955) to enable irradiation to be carried out under controlled gas conditions, and to allow removal of samples without altering the dose rate. Nitrogen containing less than 10 p.p.m. oxygen was bubbled through the suspensions to obtain anoxic conditions.

\section{RESULTS}

A typical curve for the induction of $\beta$-D-galactosidase after adding lactose to a culture of Escherichia coli strain в showed a lag of $15 \mathrm{~min}$. before measurable amounts of enzyme were detected, followed by a linear increase in concentration until $60 \mathrm{~min}$. after adding the inducer, when the concentration per bacterium became constant. It was assumed that by this time all the bacteria were fully induced and any further increase in enzyme concentration is due to growth with an increase in the number of bacteria present. When induction of $\beta$-D-galactosidase in irradiated organisms is compared with that in unirradiated organisms the slope of the linear portion of the induction curve is used to establish the surviving fraction for enzyme induction after a given dose of X-rays. Results of Pauly (1963) indicate a somewhat greater effect of $\mathrm{X}$-rays on the synthesis of a specific enzyme (lysine decarboxylase in ' $B$. cadaveris') than on total protein synthesis. In the experiment here with $\beta$-D-galactosidase the decreasing rate of enzyme synthesis may therefore be due partly to a lessening in total synthesis since this must also be affected by $\mathrm{X}$-rays. During induction in these experiments a certain amount of cell lysis occurs and this makes it difficult to correct changes in enzyme concentration for changes in turbidity that occur during induction of $\beta$-D-galactosidase. 'Surviving activity' is defined by the ratio of the slopes pertaining to irradiated and non-irradiated bacteria. By plotting the logarithm of the surviving activity against dose a curve is derived which is comparable with survival curves as conventionally plotted.

Figure 1 shows survival curves after plating Escherichia coli в on media with and without added lactose. Of the strains used, this is the most readily affected in its radiation response by slight alterations in post-irradiation conditions of growth (Alper \& Gillies, 1958 $a, 1960 b$ ). The results obtained with the four strains of $E$. coli used are shown in Table 1 and from this the following points can be made: $(a)$ There was no difference in the effect of aerobic or anoxic irradiation on synthesis of $\beta$-Dgalactosidase whether Difco or Oxoid Nutrient Broth was used for induction after irradiation. As shown by Alper \& Gillies (1958 $a, b)$, however, colony forming ability was markedly influenced by plating on comparable solid media, the influence 
being much greater after anoxic irradiation (Fig. 2). (b) With every strain of $E$. coli the oxygen enhancement ratio was higher for damage to enzyme induction than damage to colony forming ability. (c) When Oxoid Nutrient Broth was used after irradiation, the inhibition of enzyme induction was nearly as great in $E$. coli В as in

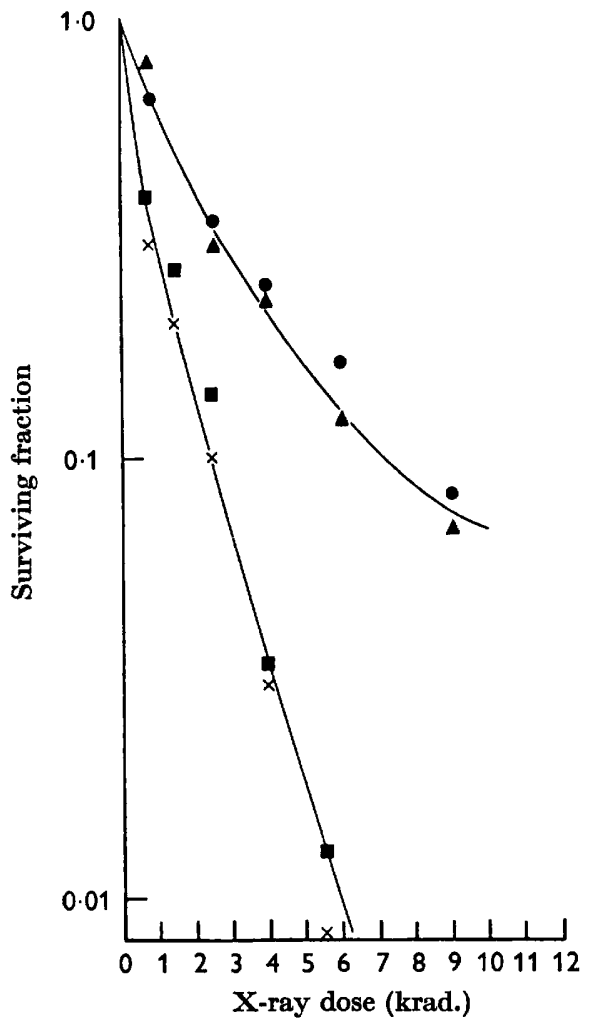

Fig. 1

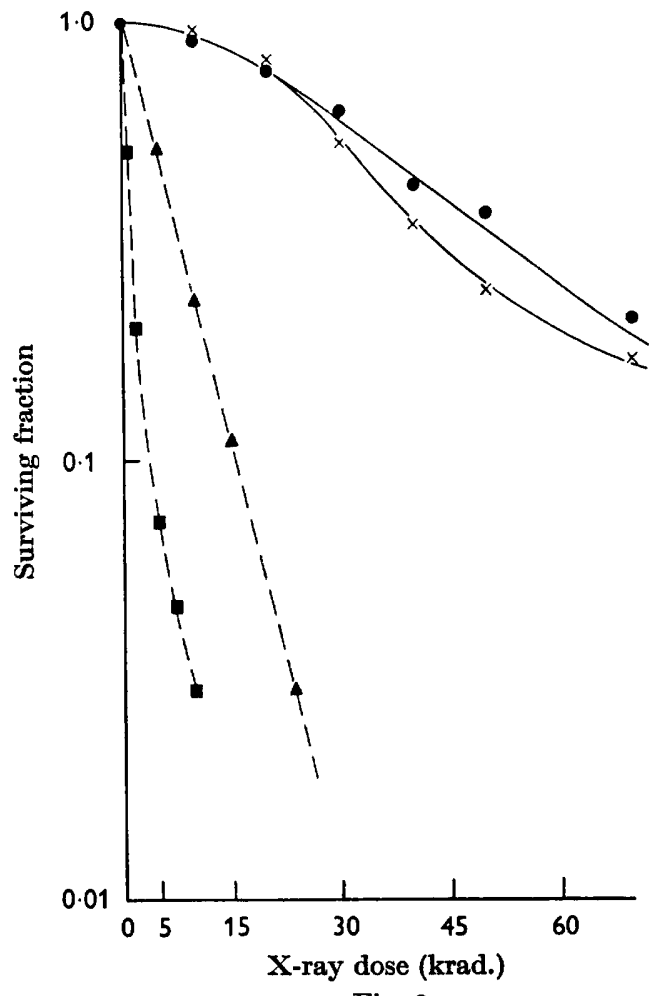

Fig. 2

Fig. 1. The effect of $\mathrm{X}$-irradiation on survival of colony forming ability in Escherichia coli strain B after exposure in buffer solution to $\mathrm{X}$-rays under oxygenation or anoxia, and subsequently incubated on Oxoid Nutrient Agar with or without added lactose. $\square$, Irradiated aerobicially and incubated without lactose; $O$, irradiated anaerobically and incubated without lactose; $x$, irradiated aerobically and incubated with lactose; $\Delta$, irradiated anaerobically and incubated with lactose.

Fig. 2. Inhibition by $X$-rays of induction of $\beta$-D-galactosidase and survival of colony formation in Escherichia coli strain B after exposure in buffer solution to X-rays in the absence of oxygen. Lactose was used as inducer for $\beta$-D-galactosidase. $\boldsymbol{O}$, Induction of $\beta$-D-galactosidase in Difco Nutrient Broth; $\times$, induction of $\beta$-D-galactosidase in Oxoid Nutrient Broth; $\Lambda$, survival of colony forming ability on Difco Nutrient Agar; a, survival of colony forming ability on Oxoid Nutrient Agar.

$E$. coli $\mathrm{B} / \mathrm{r}$, the ratio of doses to give the same effect being only $1 \cdot 3$ both for aerobic and anaerobic irradiations. This may be contrasted with their relative sensitivities to radiation-induced killing when this medium was used, the ratio of doses to give the same effect then being 7 for aerobic irradiation and 9 for anaerobic irradiation. The results for anaerobic irradiation are shown in Fig. 3. (d) Inhibition of enzyme induction in $E$. coli Bs was more sensitive than in the other three strains so that 
only about one-third of the dose was required to diminish enzyme induction to a similar degree. Survival and inhibition of enzyme induction for $\boldsymbol{E}$. coli Bs are shown graphically in Fig. 4.

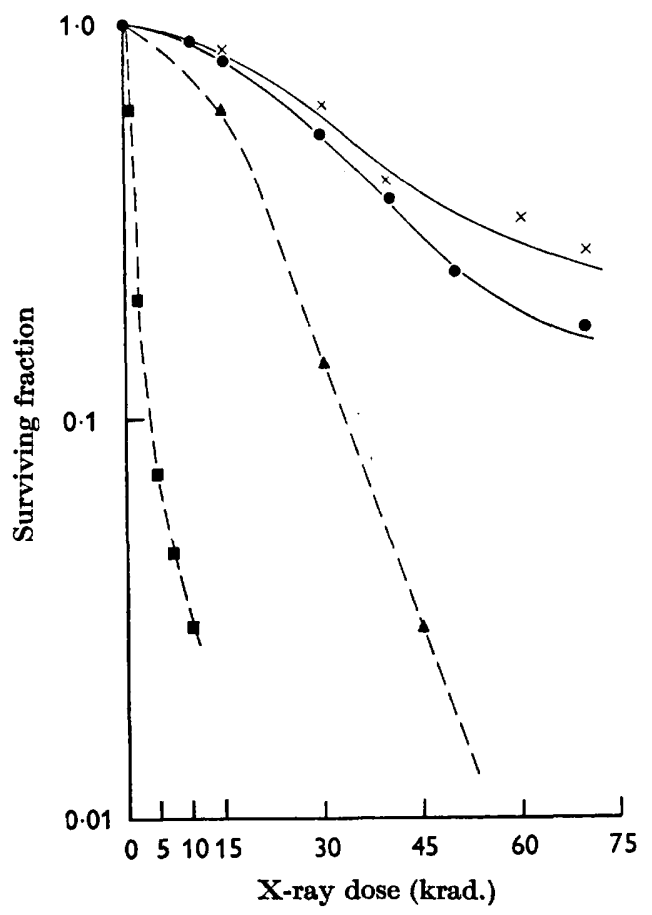

Fig. 3

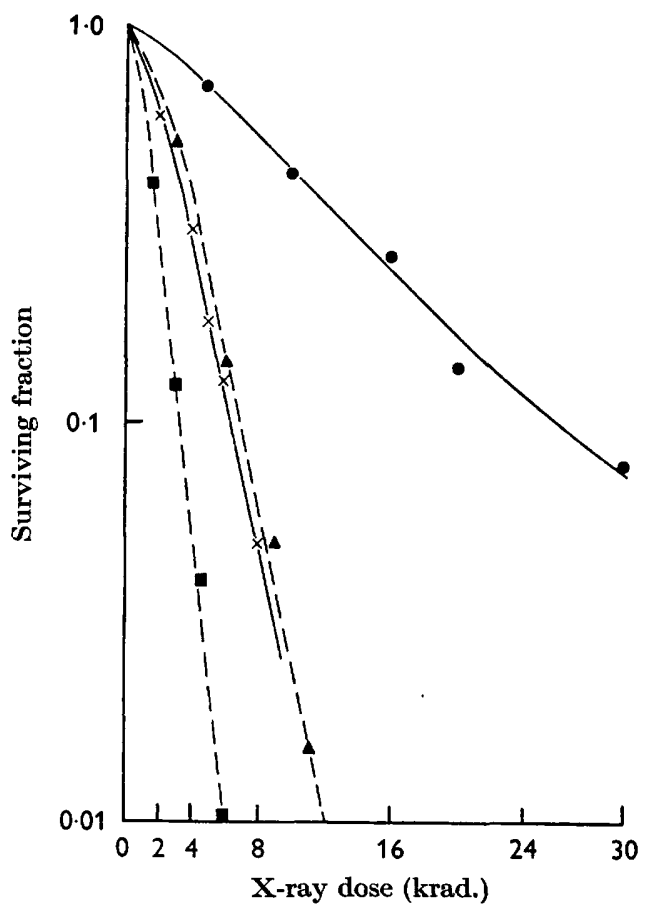

Fig. 4

Fig. 3. Inhibition by $\mathrm{X}$-rays of the induction of $\beta$-D-galactosidase and survival of colony forming ability in Escherichia coli strain B and $E$. coli strain B/r; exposure to X-rays was carried out in buffer solution and in the absence of oxygen. Oxoid Nutrient Agar was used for determining survival of colony formation and Oxoid Nutrient Broth for the survival of the induction of $\beta$-D-galactosidase. Inducer was lactose. $\times$, Induction of $\beta$-D-galactosidase in $E$. coli $\mathrm{B} / \mathrm{r} ; \boldsymbol{O}$, induction of $\beta$-D-galactosidase in $E$. coli. $\mathbf{\mathrm { B }} ; \boldsymbol{\Delta}$, survival of colony formation in $E$. coli $\mathbf{B} / \mathbf{r} ; \boldsymbol{w}$, survival of colony formation in $E$. coli $\mathbf{B}$.

Fig. 4. Inhibition of the induction of $\beta$-D-galactosidase and survival of colony formation in Escherichia coli strain Bs. A bacterial suspension in buffer solution was irradiated in the absence and presence of oxygen. Induction of $\beta$-D-galactosidase by lactose and survival of colony-forming ability was carried out with Oxoid Nutrient Broth and Oxoid Nutrient Agar respectively. $O$, Induction of $\beta$-D-galactosidase after anaerobic irradiation; $\times$, induction of $\beta$-D-galactosidase after aerobic irradiation; $\boldsymbol{\Delta}$, survival of colony formation after anaerobic irradiation; $\boldsymbol{n}$, survival of colony formation after aerobic irradiation.

\section{DISCUSSION}

These results show that the two types of radiation damage studied were differently affected by post-irradiation cultural conditions, by strain differences and by the presence of oxygen. Oxygen enhancement ratios for killing varied between $2 \cdot 1$ and 4.0 with the different strains used; with $E$. coli B variations from 1.8 to 3.5 have been observed (Alper \& Gillies, 1958 $a$; Gillies \& Alper, 1959; Alper \& Gillies, $1960 a$; Alper, 1961; Hodgkins \& Alper, 1963). The oxygen enhancement ratio for inhibition of induction was always higher than for killing and never less than 3.5. Inhibition 
of enzyme induction showed many similarities for the four strains used, which suggests that this is a more specific type of damage than cell survival. The results of Pauly (1963) indicate a somewhat greater effect of X-rays on the synthesis of a specific enzyme (lysine decarboxylase in 'Bacterium cadaveris') than on protein synthesis as a whole. Since the total synthesis must encompass that of many enzymes it seems likely that there is variation in the effects of radiation on specific enzyme systems. In previous work of my own, for example (Moore unpublished) I found that the inhibition of the synthesis of malic decarboxylase in Lactobacillus arabinosus to $37 \%$ required ten times as much ionizing radiation as did $\beta$-D-galactosidase in $\boldsymbol{E}$. coli ML 30. Thus the relationship between dose of ionizing radiation and effect on the synthesis of a specific enzyme should provide information about the radiation sensitivity of the sum of all the steps leading to the formation of that enzyme. It is clear that the induction of certain enzymes is particularly sensitive to ionizing radiations.

Table 1. The effect of aerobic and anaerobic $X$-irradiation on the inhibition of the synthesis of $\beta$-D-galactosidase and survival of colony formation in four strains of Escherichia coli

\begin{tabular}{|c|c|c|c|c|c|c|}
\hline \multirow{3}{*}{$\begin{array}{c}\text { Strains } \\
\text { of } \\
E . \text { coli }\end{array}$} & \multicolumn{4}{|c|}{ Inactivation dose* } & \multicolumn{2}{|c|}{ Oxygen enhancement ratio } \\
\hline & \multicolumn{2}{|c|}{ For survival } & \multicolumn{2}{|c|}{ For induction } & & \\
\hline & Aerobic & Anoxic & Aerobic & Anoxic & $\begin{array}{c}\text { For } \\
\text { survival }\end{array}$ & $\begin{array}{c}\text { For } \\
\text { induction }\end{array}$ \\
\hline $\mathbf{B}$ & $0 \cdot 8$ & $2 \cdot 1$ & $9 \cdot 0$ & $36 \cdot 0$ & $\mathbf{2 \cdot 6}$ & $4 \cdot 0$ \\
\hline B† & $\mathbf{2 \cdot 8}$ & $7 \cdot 0$ & $12 \cdot 0$ & $47 \cdot 0$ & $\mathbf{2} \cdot \mathbf{5}$ & $5 \cdot 0$ \\
\hline $\mathbf{B} / \mathbf{r}$ & $6 \cdot 0$ & $19 \cdot 5$ & $12 \cdot 5$ & $48 \cdot 5$ & $\mathbf{3 \cdot 3}$ & $3 \cdot 9$ \\
\hline BS & 1.8 & $3 \cdot 8$ & $3 \cdot 2$ & 11.8 & $2 \cdot 1$ & $3 \cdot 7$ \\
\hline $\mathbf{B} / \mathbf{H}$ & 4.5 & $18 \cdot 0$ & $9 \cdot 0$ & $38 \cdot 5$ & $4 \cdot 0$ & $4 \cdot 3$ \\
\hline
\end{tabular}

Inhibition of enzyme induction and survival of viability was established with Oxoid Nutrient Media for all four strains of $E$. coli.

* The inactivation doses are those required to reduce the surviving fraction of enzyme induction and viability to a value of 0.37 .

$\dagger$ For $E$. coli strain B inhibition of enzyme induction and survival of viability was established with Difco Nutrient Media.

Dewey (1962) reported that induction of histidine oxidizing enzymes in a strain of Pseudomonas was half as radiosensitive as survival. Induction of $\beta$-D-galactosidase in $E$. coli strains $\mathrm{Bs}, \mathrm{B} / \mathrm{r}, \mathrm{B} / \mathrm{H}$ was one-half to one-third as radiosensitive as survival, but in $E$. coli strain B induction was one-tenth as radiosensitive as survival when Oxoid medium was used. The oxygen enhancement ratios for inhibition of $\beta$-D-galactosidase in all strains of $\boldsymbol{E}$. coli used in this present work varied between 3.7 and 4.3 and both Pauly (1963) and Dewey (1962) reported oxygen enhancement ratios of value about 4 for inhibition of other inducible systems.

Jacob \& Monod (1961) suggest that induction of $\beta$-D-galactosidase requires specific pieces of DNA for its expression. The importance of DNA has been endorsed by the work of Novelli, Kameyama \& Eisenstadt (1961). These authors reported that the induction of $\beta$-D-galactosidase in a bacterial extract obtained from irradiated Escherichia coli was absent until the addition of DNA from unirradiated induced bacteria. This work of Novelli et al. (1961) might suggest that the integrity of the enzyme synthesizing system depends only on the presence of undamaged 
DNA. However, the present work, and that of others (Dewey, 1962; Pauly, 1963) throws some doubt on the concept that radiation damage to DNA is solely responsible for the inhibition of enzyme synthesis. This doubt arises in part from the magnitude of the oxygen enhancement ratios. From work which is more specificially concerned with damage to DNA the oxygen enhancement ratios have been much smaller. Anderson (1951) reported that a radiation-induced back mutation had a smaller oxygen enhancement ratio than killing. More recently Bridges (1963) and Deering (1963) have reported similar observations. Howard-Flanders, Levin \& Theriot (1963) reported an oxygen enhancement ratio of 1.8 for inactivation of $T_{2}$ bacteriophage after it had been injected into the host. In these model systems oxygen enhancement ratios are considerably lower than those reported for lethal effects (Alper, 1963), so the high oxygen enhancement ratios seen in experiments with inducible systems may indicate that damage to some part of the induction system other than DNA is responsible.

It is possible to estimate 'target size' for a given end-point from the dose required $\left(D_{37}\right)$ to give an average of one damaging event per cell (Lea, 1946). The $D_{37}$ value of $42 \pm 6 \mathrm{krad}$. for inhibition of $\beta$-D-galactosidase in three strains of Escherichia coli is similar to that reported by Pauly (1963) for lysine decarboxylase. $D_{37}$ values after anaerobic irradiations have been used to calculate the approximate molecular weight of inactivated enzymes (Pollard et al. 1955; Pollard \& Barrett, 1959). If the doses of radiation to reduce the surviving fraction to $37 \%$ for enzyme induction are used in conjunction with Pollard's formula, the site responsible for induction has a molecular weight of 25 million, similar to that deduced by Pauly (1959) for induction of lysine decarboxylase. Electron microscope studies have suggested that the messenger RNA involved in the synthesis of $\beta$-D-galactosidase is 1.5 million (Kioh \& Rich, 1964). Therefore the molecular weight determination based on inhibition of enzyme induction under anoxic conditions yields a molecular weight that is too large to be appropriate for the corresponding piece of DNA code. This may be further evidence suggesting that not only damage to DNA is being observed and that it is some other form of damage which is responsible for the high values of oxygen enhancement ratio.

The author wishes to thank Miss T. Alper for advice given during this work and during the preparation of the manuscript.

\section{REFERENCES}

AlPER, T. (1955). Bacteriophage as indicator in radiation chemistry. Radiat. Res. 2, 119.

Alper, T. (1961). Variability of the oxygen effect observed with micro-organisms. Part II. Escherichia coli B. Int. J. Radiat Biol. 3, 369.

AlPer, T. (1963). Lethal mutations and cell death. Physics Med. Biol. 8, 365.

AlPER, T. \& Gillies, N. E. (1958a). Restoration of Escherichia coli strain B after irradiation: its dependence on suboptimal growth conditions. J. gen. Microbiol. 18, 461 .

Alper, T. \& Gillies, N. E. (1958b). 'Restoration' of micro-organisms and suboptimal growth conditions. Radiat. Res. 9, 86.

Alper, T. \& Gillies, N. E. (1960a). The influence of metabolic events immediately after irradiation on the difference in sensitivity between $E$. coli в and E. coli $\mathbf{B} / \mathrm{r}$. 'Immediate and low level effects of ionizing radiations' Proceedings of Symposium held at Venice, June 22-26, 1959. Edited by A. A. Buzzati-Traverso, p. 205. London: Taylor \& Francis, Ltd. 
Alper, T. \& Gillies, N. E. $(1960 b)$. The relationship between growth and survival after irradiation of Escherichia coli strain B and two resistant mutants. J. gen. Microbiol. 22, 113.

Anderson, E. H. (1951). The effect of oxygen on mutation induced by X-rays. Proc. natn. Acad. Sci., U.S.A. 37, 340.

Billen, D. \& Lichstein, H. C. (1952). The effect of X-radiation on the adaptive formation of formic hydrogenlyase in Escherichia coli. J. Bact. 63, 533.

Bridges, B. A. (1963). Effect of chemical modifiers on inactivation and mutation by gamma radiation in Escherichia coli. J. gen. Microbiol. 31, 405.

Defring, R. (1963). Mutations and killing of Escherichia coli wP-2 by accelerated heavy ions and other radiations. Radiat. Res. 19, 169.

Dewey, D. L. (1962). X-ray inactivation of inducible enzyme synthesis and the effect of oxygen and glycerol. Nature, Lond. 194, 158.

Grumes, N. E. \& Alper, T. (1959). Reductions in the lethal effects of radiations on Escherichia coli B by treatment with chloramphenicol. Nature, Lond. 183, 237.

Gros, F. (1960). The Nucleic Acids, vol. III, p. 409. Ed. E. Chargaff \& J. N. Davidson, New York: Academic Press.

Hodgkins, B. \& Alper, T. (1963). Anaerobic growth as a factor influencing radio-sensitivity. J. gen. Microbiol. 30, 307.

Howard-Flanders, P., Levin, J. \& Theriot, L. (1963). Reaction of desoxyribonucleic acid radicals with sulphydryl compounds in X-irradiated bacteriophage systems. Radiat. Res. 18, 593.

JACOB, F. \& MonoD, J. (1961). Genetic regulatory mechanisms. J. molec. Biol. 3, 318.

Kameyama, T. \& Novelli, G. D. (1962). Effect of ultraviolet inactivation and photoactivation on the induced synthesis of $\beta$-galactosidase by Escherichia coli. Arch. Biochem. Biophys. 97, 529.

Kroн, Y. \& Rich, A. (1964). Induced enzyme formed on bacterial polyribosomes. Proc. natn. Acad. Sci., U.S.A. 51, 111.

LEA, D. E. (1946). Actions of Radiation on Living Cells. Cambridge University Press.

LEDERBERG, J. (1950). $\beta$-D-Galactosidase of $E$. coli $\times 12$. J. Bact. 60, 381.

Noveli, G. D., Kameyama, T. \& Eisenstadt, J. M. (1961). The effect of ultraviolet light and $\mathrm{X}$-rays on an enzyme forming system. J. cell. comp. Physiol. 58, 225.

Pauly, H. (1959). X-ray sensitivity and target volume of enzyme induction. Nature, Lond. 184, 1570.

Pauly, H. (1963). Synthesis of protein, RNA, DNA and induced enzyme in Bacterium cadaveris after X-irradiation. Int. J. Radiat. Biol. 6, 221.

Pollard, E. C. \& Barrett, N. (1959). The radiation sensitivity and molecular weight of dry $\beta$-galactosidase. Radiat. Res. 11, 781.

Pollard, E. C., Guild, W. R., Hutchinson, F. \& Setlow, R. B. (1955). The direct action of ionising radiation on enzymes and antigens. Prog. Biophys. biophys. Chem. 5, 72.

Pollard, E. C. \& Vogler, C. (1961). Radiation action on some metabolic processes in Escherichia coli. Radiat. Res. 15, 109.

Swenson, P. A. \& Setrow, R. B. (1964). $\beta$-Galactosidase: inactivation of its messenger RNA by ultraviolet irradiation. Science, 146, 791 . 